\title{
Climate Change Impacts and Adaptation of Households in U-Tapao River Sub-Basin, Thailand
}

\author{
Chanisada Choosuk $^{1 *}$, Somporn Khunwishit ${ }^{2}$, Panalee Chevakidagarn ${ }^{1}$ \\ ${ }^{1}$ Faculty of Environmental Management, Prince of Songkla University, Songkhla 90112, Thailand \\ ${ }^{2}$ Faculty of Management Sciences, Prince of Songkla University, Songkhla 90112, Thailand
}

Corresponding Author Email: chanisada.c@psu.ac.th

https://doi.org/10.18280/ijsdp.160610

Received: 7 September 2021

Accepted: 19 October 2021

\section{Keywords:}

climate change adaptation, health adaptation, household, Thailand

\begin{abstract}
Flood, storm, and drought have frequently impacted households in the U-Tapao River Subbasin, Songkhla Province, Thailand, as a result of climate change. Studying how to assist them in better adapting to the effects of climate change is a critical mission that researchers should strive to achieve. The goals of this study are to (1) investigate the effects of climate change on households in the U-Tapao River Sub-basin, (2) examine the adaptation strategies they used, (3) the challenges they faced when attempting to adapt, and (4) provide recommendations for future adaptation. The study was carried out in the jurisdictions of three local government authorities. A survey questionnaire was used to collect quantitative data from 300 households, which was then analyzed using frequency, percentage, mean, and standard deviation. To supplement survey data, qualitative data were collected from 50 key informants via in-depth interviews and focus-group discussions. Climate change impacted households in four ways, according to the findings: health, housing, agriculture, and livelihood activities. Although households can take general measures to mitigate the effects of climate change on their health and livelihood, they do not appear to be able to take preventive measures to minimize flooding impacts on their house and property, nor do they appear to be able to adopt on-farm adaptation strategies to prevent income loss. The main impediment to taking more effective measures is a lack of funds, knowledge, and technical assistance. As a result, practical recommendations are provided at the end of this paper to help overcome such challenges and encourage households to adopt more adaptation strategies.
\end{abstract}

\section{INTRODUCTION}

Because of its global and local effects, climate change is no longer a new or unfamiliar concept. It is already having an impact on people's livelihoods and will continue to do so in the coming decades $[1,2]$. As a result, reducing its effects on humans and the environment is an important and urgent priority for everyone. Adapting to climate change is one way to achieve the ultimate goal of reducing its effects. The IPCC defines climate change adaptation, which has recently gained prominence, as "adjustment to an actual or expected environment and its effects" [3]. This concept refers to minimizing negative consequences, minimizing damage, and maximizing potential benefits from changes. It is also related to time scale in terms of doing what when (such as focusing on immediate actions in response to rapid climate change that has already occurred) and focusing on proactive and precautionary measures in response to expected future impacts. Finally, because households seek to secure their lives and well-being at the community and city levels, it is a multilevel sector-based endeavor [2, 4-7].

Scholars have previously conducted research studies to identify climate-related risks that posed a threat to households. Here are some intriguing findings from previous research. For starters, the health effects of climate-related risks will affect most communities in the coming decades, threatening the lives and well-being of billions of people [8]. The effects of climate change on the immune and respiratory systems stand out among these health risks. Temperature, rainfall, and relative humidity, for example, have all been linked to dengue epidemics [9]. Second, the impact of climate change, particularly drought and flooding, has had an effect on both urban systems and household livelihoods. It can, for example, cause significant damage to homes and possessions as well as communications disruption [10,11]. Flooding is especially dangerous in urban areas, densely populated areas, and areas with aging infrastructure [12]. Finally, agriculture is one of the most vulnerable sectors because farmers rely heavily on adequate rainfall. Prolonged drought and severe flooding caused by climate change can destroy people's plantation or agricultural activities [13]. This, in turn, can exacerbate rural households' food insecurity. Furthermore, climate change has the potential to exacerbate the problem of pests and diseases [14-16]. Previous studies examined climate change adaptation using a variety of methodologies. Selm et al. [11], Somboonsuke et al. [17], Lin et al. [18], and Harvey et al. [19] used quantitative methods to survey household and farmer perceptions and impacts. Other researchers have used qualitative techniques such as in-depth interviews and focus groups, including Aniah et al. [2], Tahiru et al. [6], Lehmann et al. [20], Birchall and Bonnett [21], and Artur and Hilhorst [22]. Finally, some studies used mixed methods, such as 
Tonmoy et al. [1], Assan et al. [14], and Zhai et al. [23], which used both quantitative and qualitative methods to study farmers' and households' adaptation to climate change. Our study follows Tonmoy et al. [1], Assan et al. [14], and Zhai et al. [23] in examining climate change impacts and adaptation of residents in the U-Tapao River Sub-basin using mixed methodologies. Data collected using multiple methodologies can provide more reliable results, which can help to strengthen research conclusions [24, 25].

Thailand, like many other countries, is experiencing climate change effects such as flooding, drought, and rising sea levels [26]. Climate change has had an impact on households in many parts of the country. Thus, it is critical to find ways to assist them in better coping with such consequences. As a result, the purpose of this study is to investigate the effects of climate change on households in the U-Tapao River Sub-basin, examine the adaptation strategies they used, the challenges they encountered when attempting to adapt, and, finally, provide recommendations for future adaptation.

\section{METHODOLOGY}

\subsection{Study areas}

The study was carried out in three local government authorities in Songkhla Province's U-Tapao River Sub-basin, namely Prik Subdistrict Administrative Organization (PSAO), Patong Subdistrict Municipality (PTSM), and Klong Hae Town Municipality (KHTM). The three areas are exposed and vulnerable to the effects of climate change, particularly flooding. As shown in Figure 1, three research areas were selected to represent the upper, middle, and lower parts of the $\mathrm{U}$-Tapao river. PSAO represented for agricultural areas and is located in the upper part of the U-Tapao River Sub-basin. PTSM is located in the heart of the U-Tapao River Sub-basin, and the surrounding areas are mostly used for agricultural, industrialization, and commercialization. The main para rubber factories in Songkhla Lake Basin's are located in PTSM. KHTM is located in the lower U-Tapao River Sub-basin and is composed of both urban and agricultural areas. KHTM is a low-lying, flood-prone area that absorbs floodwaters downstream of the U-Tapao River.

\subsection{Samples and key informants}

Because this study used a mixed method (quantitative and qualitative). Households are used as our unit of analysis to examine the levels of climate change impact, current adaptation, and adaptation challenges. Using a quota sampling system, 100 households in each area (a total of 300 households from three areas) were randomly chosen to participate in the survey (using a questionnaire as the main research instrument). This equal distribution of the three areas would be useful for comparison purposes. Our sampling strategy began with identifying areas that were frequently impacted by flooding from upstream to downstream of the U-Tapao River and had varying types of contexts. Three administrative units were purposefully chosen based on these criteria: Prik Subdistrict Administrative Organization (PSAO), Patong Subdistrict Municipality (PTSM), and Klong Hae Town Municipality (KHTM). Each of these administrative units has characteristics that are relevant to our research. Firstly, they were all in flood-prone areas. Secondly, PSAO was an upstream area with an agricultural context, PSAO was a midstream area with an industrial context, and KHTM was a downstream area with a semi-urbanized context. Following that, households were drawn at random from these administrative units. We decided to create a sample of 300 households due to budgetary and time constraints. The administrative units were then subjected to a quota system in which 100 households were chosen at random from each administrative unit. The questionnaires were then hand delivered to each household to ensure that they were fully returned and that a 100 percent response rate was achieved. In addition, qualitative data were gathered to supplement quantitative data findings. As a result, $50 \mathrm{key}$ informants from all three areas were interviewed in-depth and participated in a focus-group discussion. Community members and local government officials are among these key informants.

\subsection{Data collection and analysis}

The data was collected between January and March of 2017. A questionnaire with yes-no, Likert-scale, and open-ended questions was used to collect quantitative data. This questionnaire served as the primary research tool for gathering information about households' sociodemographic characteristics, perceived impacts of climate change, adaptation practices, and challenges. The questionnaire includes questions such as, "How would you rate the impact of climate change on your health, house, agriculture, and daily life activities?" Did you use any of the 18 adaptation strategies listed below? Did you identify the following five factors or situations as climate change adaptation challenges? Quantitative survey data were then analyzed using descriptive statistics such as frequency, percentage, mean, and standard deviation. For qualitative data, an interview guide was used as a research instrument to collect data from 50 key informants from three areas via in-depth interviews and focus-group discussions. Following that, qualitative data were analyzed using a content analysis technique

\section{RESULTS}

\subsection{Sociodemographic profile}

The survey included 300 households, with 31.7 percent of respondents being men and 68.3 percent being women. On average, respondents were 48.9 years old. The majority of these respondents had a lower level of education than a university graduate (80.3 percent). Farmers made up 38.3 percent of those polled, while small business owners (or selfemployed) made up 29 percent. With an average of 5 family members, the majority of respondents $(82.0$ percent $)$ reported a monthly household income of 10,000 to 20,000 Thai Baht (approximately 312 to 624 US dollars).

\subsection{Area climate-risk profile}

The U-Tapao River Sub-basin is part of the Songkhla Lake Basin in Thailand. The basin stretches across three provinces (Songkhla, Phatthalung, and Nakon Si Thammarat) and encompasses an area of 8,729 kilometers, including 1,017 kilometers of main lake water body [27]. The U-Tapao River Sub-basin is a mixed-use watershed, according to Chuvanich et al. [28]. It contains forest land, agricultural land, industrial 
land, livestock, and community areas. Agriculture occupied 74.14 percent of the land area in 2012 (Figure 1), according to Chuvanich et al. [28]. Rubber plantation accounts for the majority of this agricultural land use, accounting for 65.58 percent of the total area. In terms of industrial use, the UTapao River watershed contains approximately 300 factories, the majority of which are located near the U-Tapao River, making them exposed and vulnerable to flooding [28].

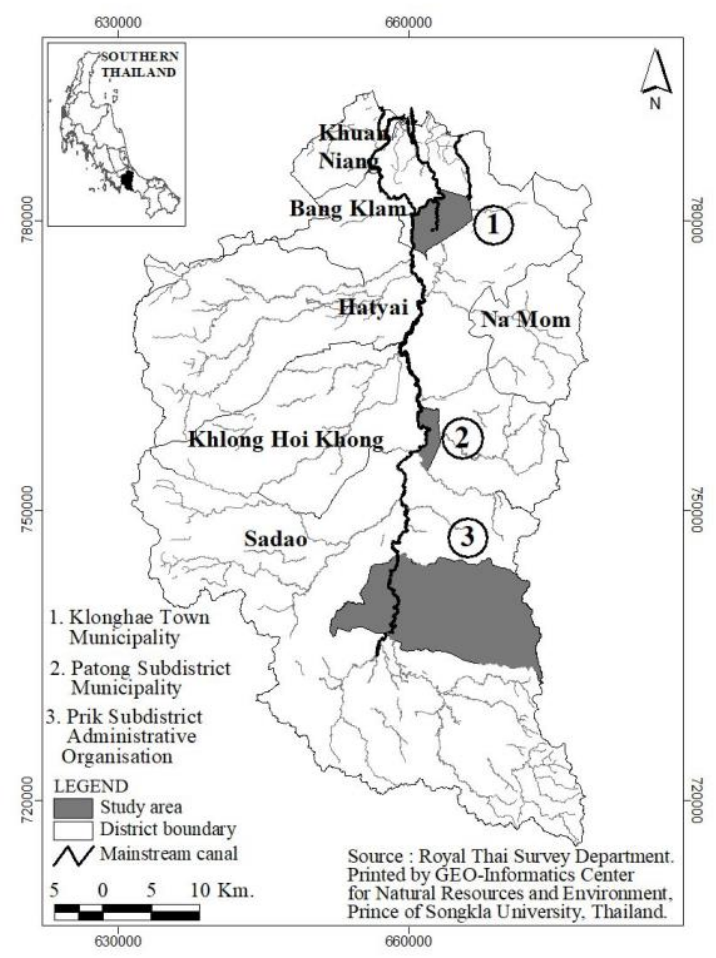

Figure 1. U-Tapao River Sub-basin [29]

\subsection{Climate change impacts}

\subsubsection{Climate change impacts on health}

According to our data, the climatic impact on health was greatest in KHTM $(\mathrm{M}=3.05)$, followed by PTSM $(\mathrm{M}=2.85)$ and PSAO $(M=2.84)$, respectively. Although data from PSAO appeared to be more dispersed than others, as evidenced by the highest value of standard deviation (1.107), overall data from these three areas did not deviate significantly from the mean, as indicated by standard deviation values ranging from $0-1$. As a result, the mean values are satisfactory. Climate change could cause allergy symptoms, respiratory problems, and a dengue fever outbreak, among other things. People in three areas of the U-Tapao River Sub-basin appeared to be affected by such climatic effects on health. "Temperatures have risen," said one KHTM resident. "We were suffering from respiratory allergies and couldn't breathe properly." Furthermore, a PSAO resident stated that "climate change has made extreme weather more dangerous to our health, especially for the elderly and young in our community." "The disease was spread most dangerously by Aedes mosquitos, which reproduced in favorable conditions. Because of the prolonged rains, mosquitoes were able to lay their eggs in water-holding containers, such as rubber leaves, in PSAO agricultural areas. From children to adults, the disease has spread."

\subsubsection{Climate change impacts on housing}

The impact of climate change on housing appeared to differ between the three areas. The greatest impact on housing was in PTSM (M=3.10), followed by KHTM $(M=3.01)$, and PSAO $(\mathrm{M}=2.54)$. The standard deviation of 1.058 indicated that PSAO data appeared to be more dispersed than others. However, as indicated by standard deviation values ranging from $0-1$, data from these three areas did not deviate significantly from the mean. As a result, the mean values are acceptable. This is understandable given that the majority of the PTSM area consists of communities and factories. Because many people in this area work in factories, they chose to live in communities close to their workplaces. Unfortunately, the majority of these communities were built near the U-Tapao River, making houses more vulnerable to flooding. When massive flooding occurred, most one-story houses were frequently affected by the floods. These are the same reasons as in the case of KHTM. However, in the case of PSAO, the impact of housing was relatively lower than in the other two areas because houses were elevated to reduce the impact of flooding in this agricultural society.

\subsubsection{Climate change impacts on agriculture}

When the effects of climate change on agriculture were compared, PSAO households were found to be the most impacted $(\mathrm{M}=3.23)$, followed by KHTM $(\mathrm{M}=2.93)$ and PTSM $(\mathrm{M}=2.17)$. Data from PTSM appeared to be more dispersed than others in terms of agricultural impact. However, as indicated by standard deviation values close to one, data from all three areas did not deviate significantly from the mean. As a result, the average values remain acceptable. This makes sense given that the majority of PSAO households were farmers who grew para-rubber, palm oil, and orchards. According to some PSAO key informants, "climate change effects such as drought and flooding have reduced our farming yields in recent years". These are the same reasons that were given in the case of KHTM. However, in the case of PTSM, where the majority of households worked in factories or were self-employed, the impact on agriculture was lower than in the other two areas.

\subsubsection{Climate change impacts on livelihood activities}

In terms of the impact on general livelihood activities, the results were quite similar, with medium-level impacts in all three areas. When examined more closely, the impact in KHTM $(M=3.32)$ appeared to be the greatest, followed by PSAO $(M=3.26)$ and PTSM $(M=3.15)$. Data from the three areas did not deviate significantly from the mean (standard deviation values close to one), implying that the obtained mean values are acceptable (Table 1).

Table 1. Perceived impacts of climate change

\begin{tabular}{ccccccc}
\hline \multirow{2}{*}{$\begin{array}{c}\text { Impacts } \\
(\mathbf{n}=\mathbf{3 0 0})\end{array}$} & \multicolumn{2}{c}{$\begin{array}{c}\text { PSAO } \\
(\mathbf{n}=\mathbf{1 0 0})\end{array}$} & \multicolumn{2}{c}{$\begin{array}{c}\text { PTSM } \\
(\mathbf{n}=\mathbf{1 0 0})\end{array}$} & \multicolumn{2}{c}{$\begin{array}{c}\text { KHTM } \\
(\mathbf{n}=\mathbf{1 0 0})\end{array}$} \\
\cline { 2 - 7 } $\mathbf{M}$ & $\mathbf{S D}$ & $\mathbf{M}$ & $\mathbf{S D}$ & $\mathbf{M}$ & $\mathbf{S D}$ \\
\hline $\begin{array}{c}\text { Impact on } \\
\text { health }\end{array}$ & 2.84 & 1.107 & 2.85 & 0.967 & 3.05 & 0.925 \\
\hline $\begin{array}{c}\text { Impact on } \\
\text { housing }\end{array}$ & 2.54 & 1.058 & 3.10 & 0.846 & 3.01 & 0.893 \\
\hline $\begin{array}{c}\text { Impact on } \\
\text { agriculture }\end{array}$ & 3.23 & 1.126 & 2.17 & 1.200 & 2.93 & 1.06 \\
\hline $\begin{array}{c}\text { Impact on } \\
\text { livelihood } \\
\text { activities }\end{array}$ & 3.26 & 1.097 & 3.15 & 1.008 & 3.32 & 0.919 \\
\hline
\end{tabular}

\subsection{Climate change adaptation}

According to the percentage of households that chose each 
adaptation strategy, as shown in Table 2, climate change adaptation practices adopted by households in the U-Tapao River Sub-basin can be classified into four dimensions: health and well-being adaptation, housing adaptation, agricultural adaptation, and livelihood activity adaptation.

\subsubsection{Climate change adaptation on health and well-being}

Households from all three areas tended to prefer the following two adaptation practices to other measures in the same category: (1) preparing prescription medications and having a first-aid kit on hand $(\mathrm{PSAO}=89$ percent, KHTM $=$ 88 percent, $\mathrm{PTSM}=81$ percent $)$ and (2) preparing personal hygiene items and personal care $(\mathrm{KHTM}=87$ percent, $\mathrm{PSAO}$ $=86$ percent, $\mathrm{PTSM}=83$ percent). Preparing extra cash for emergency situations, on the contrary, was the least preferred adaptation practice across all three areas $(\mathrm{KHTM}=68$ percent, PTSM $=64$ percent, $\mathrm{PSAO}=60$ percent .

\subsubsection{Climate change adaptation on housing}

In this study, housing adaptation consists of two strategies: (1) elevating and reinforcing the house structure and (2) constructing barricades to prevent flooding and preparing sand bags to create a flood barrier. The findings revealed that adoption of these two housing strategies was low in all three areas. Only 29 percent of PSAO households, 36 percent of PTSM households, and 52 percent of KHTM households used the first strategy, elevating and reinforcing house structure. Similarly, only 15 percent of PSAO households, 33 percent of PTSM households, and 18 percent of KHTM households had implemented the second strategy (building barricades to prevent flooding and preparing sand bags to create a flood barrier). The findings imply that, when it comes to climate change adaptation, practices that necessitate structural changes, which are inevitably associated with a significant financial outlay, may not be popular options for people with low to medium income. The following figures show housing adaptation choices in U-Tapao River Sub-basin. Figure 2 illustrated the entire house being raised according to the estimated highest level of flood-water in the past. Figure 3 showed the non-permanent replenishment of the kiosk's inventory. Figure 4 showed the concrete structure that was adapted to the existing house to prevent floods.

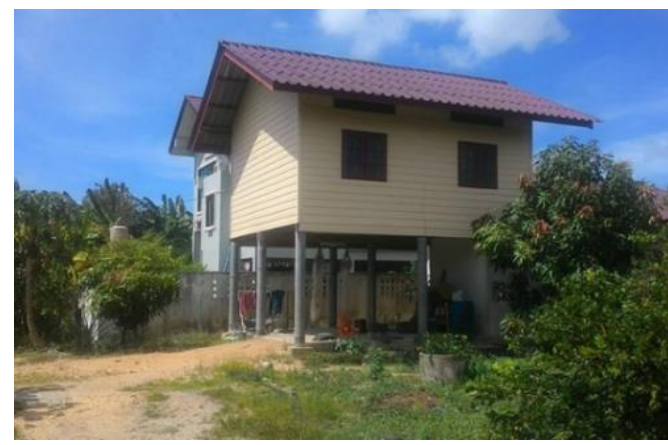

Figure 2. Stilted-house in KHTM

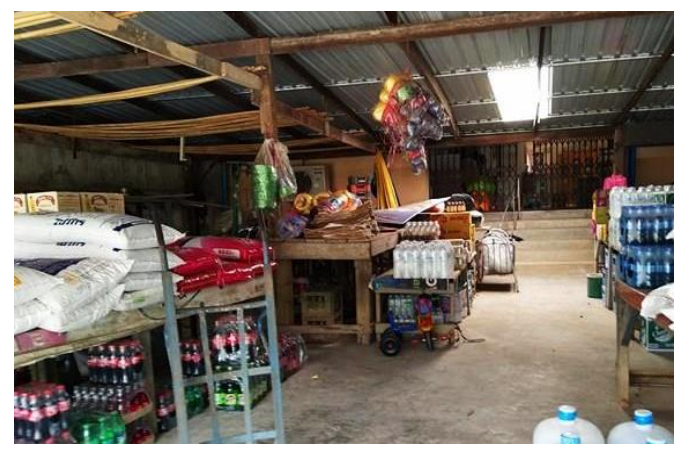

Figure 3. Storage of belongings on higher platform in Patong Market

Table 2. Climate change adaptation at the household level

\begin{tabular}{|c|c|c|c|c|c|c|}
\hline \multirow[b]{2}{*}{ Climate change adaptation $(n=300)$} & \multicolumn{2}{|c|}{ PSAO $(n=100)$} & \multicolumn{2}{|c|}{ PTSM $(n=100)$} & \multicolumn{2}{|c|}{ KHTM $(n=100)$} \\
\hline & $\begin{array}{l}\text { Adapt } \\
(\%)\end{array}$ & $\begin{array}{l}\text { Not adapt } \\
(\%)\end{array}$ & $\begin{array}{l}\text { Adapt } \\
(\%)\end{array}$ & $\begin{array}{l}\text { Not adapt } \\
(\%)\end{array}$ & $\begin{array}{l}\text { Adapt } \\
(\%)\end{array}$ & $\begin{array}{l}\text { Not adapt } \\
(\%)\end{array}$ \\
\hline \multicolumn{7}{|l|}{ Health \& Well-being adaptation } \\
\hline $\begin{array}{l}\text { Preparing prescription medications and having a first-aid kit on } \\
\text { hand }\end{array}$ & 89.0 & 11.0 & 81.0 & 19.0 & 88.0 & 12.0 \\
\hline Preparing personal hygienic items and personal care & 86.0 & 14.0 & 83.0 & 17.0 & 87.0 & 13.0 \\
\hline Preparing rice and nonperishable food & 76.0 & 24.0 & 80.0 & 20.0 & 79.0 & 21.0 \\
\hline $\begin{array}{l}\text { Preparing extra cash for emergency situations } \\
\text { Housing adaptation }\end{array}$ & \multicolumn{5}{|c|}{ Housing adaptation } & 32.0 \\
\hline Elevating and reinforcing house structure & 29.0 & 71.0 & 36.0 & 64.0 & 52.0 & 48.0 \\
\hline $\begin{array}{l}\text { Building barricades to prevent flood \& preparing sand bags to } \\
\text { create flood barrier }\end{array}$ & 15.0 & 85.0 & 33.0 & 67.0 & 18.0 & 82.0 \\
\hline \multicolumn{7}{|l|}{ Agricultural adaptation } \\
\hline Changing plant dates/ rubber tapping period & 23.0 & 77.0 & 12.0 & 88.0 & 16.0 & 84.0 \\
\hline Changing crop/rubber types & 19.0 & 81.0 & 10.0 & 90.0 & 10.0 & 90.0 \\
\hline Making the drainage trench in the rubber plantation & 26.0 & 74.0 & 10.0 & 90.0 & 16.0 & 84.0 \\
\hline Switching to drought- and flood-tolerant varieties & 26.0 & 74.0 & 7.0 & 93.0 & 9.0 & 91.0 \\
\hline Planting intercropping/ mixed cropping & 35.0 & 65.0 & 11.0 & 89.0 & 20.0 & 80.0 \\
\hline Changing livestock management practices & 23.0 & 77.0 & 10.0 & 90.0 & 16.0 & 84.0 \\
\hline Switching to livestock variety & 17.0 & 83.0 & 7.0 & 93.0 & 12.0 & 88.0 \\
\hline Doing secondary occupations & 48.0 & 52.0 & 22.0 & 78.0 & 52.0 & 48.0 \\
\hline $\begin{array}{c}\text { Agriproduct processing to generate additional income } \\
\text { Livelihood activity adaptation }\end{array}$ & 22.0 & 78.0 & 13.0 & 87.0 & 24.0 & 76.0 \\
\hline Checking the weather regularly & 72.0 & 28.0 & 68.0 & 32.0 & 84.0 & 16.0 \\
\hline Making sure that everything is ready before going to work & 81.0 & 19.0 & 75.0 & 25.0 & 92.0 & 8.0 \\
\hline $\begin{array}{l}\text { Checking the flood-risk roads to avoid flooded routes and } \\
\text { preparing a boat }\end{array}$ & 72.0 & 28.0 & 72.0 & 28.0 & 74.0 & 26.0 \\
\hline
\end{tabular}


Table 3. Climate change adaptation challenges for households

\begin{tabular}{|c|c|c|c|c|c|c|}
\hline \multirow{2}{*}{$\begin{array}{c}\text { Challenges faced } \\
\qquad(\mathrm{n}=\mathbf{3 0 0})\end{array}$} & \multicolumn{2}{|c|}{$\begin{array}{c}\text { PSAO } \\
(n=100)\end{array}$} & \multicolumn{2}{|c|}{$\begin{array}{c}\text { PTSM } \\
(\mathbf{n}=100)\end{array}$} & \multicolumn{2}{|c|}{$\begin{array}{l}\text { KHTM } \\
(n=100)\end{array}$} \\
\hline & $\begin{array}{l}\text { Yes } \\
(\%)\end{array}$ & $\begin{array}{l}\text { No } \\
(\%)\end{array}$ & $\begin{array}{l}\text { Yes } \\
(\%)\end{array}$ & $\begin{array}{l}\text { No } \\
(\%)\end{array}$ & $\begin{array}{l}\text { Yes } \\
(\%)\end{array}$ & $\begin{array}{l}\text { No } \\
(\%)\end{array}$ \\
\hline Lack of funds for adaptation & 82.0 & 18.0 & 67.0 & 33.0 & 73.0 & 27.0 \\
\hline Lack of knowledge about climate change adaptation practices & 61.0 & 39.0 & 55.0 & 45.0 & 67.0 & 33.0 \\
\hline Inadequate support from both local and provincial government agencies & 63.0 & 37.0 & 55.0 & 45.0 & 55.0 & 45.0 \\
\hline Inadequate cooperation among community members & 44.0 & 56.0 & 52.0 & 48.0 & 58.0 & 42.0 \\
\hline Lack of information on climate change and adaptation techniques from related agencies & 47.0 & 53.0 & 29.0 & 71.0 & 45.0 & 55.0 \\
\hline
\end{tabular}

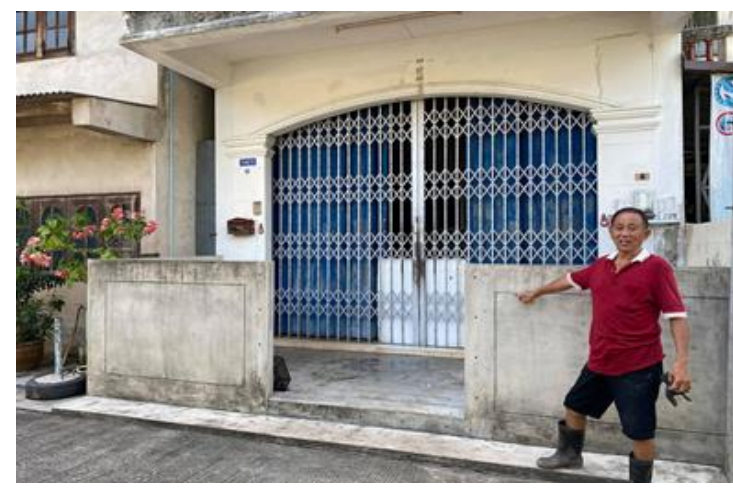

Figure 4. Flood barriers were constructed to prevent the water flow in PTSM

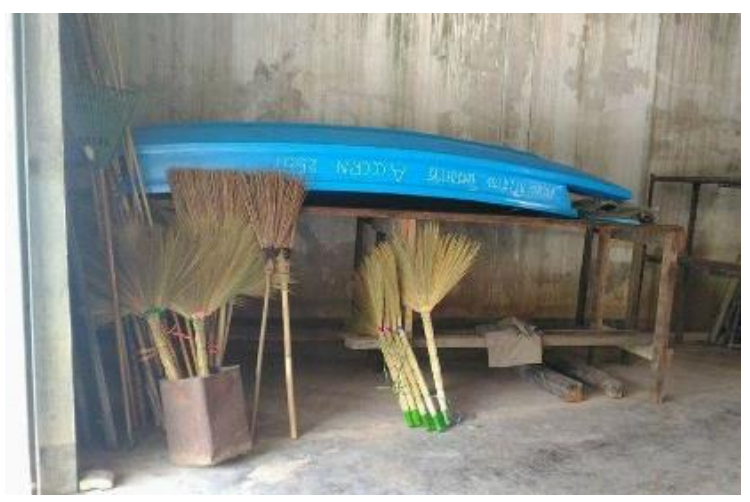

Figure 5. Boat kept under the house in PTSM

\subsubsection{Climate change adaptation on agriculture}

This study looked at nine agricultural adaptation measures: (1) changing plant dates/ rubber tapping period, (2) changing crop/rubber types, (3) digging a drainage trench in the rubber plantation, (4) switching to drought- and flood-tolerant varieties, (5) planting intercropping/mixed cropping, (6) changing livestock management practices, (7) switching to livestock variety, (8) doing secondary occupations, and (9) agriproduct processing to generate additional income. Surprisingly, the findings revealed that only a small proportion of households in all three areas had implemented these adaptation strategies. In all three areas, less than half of the households took these measures. Measure number 8 , on the other hand, was taken by more than half of all households (doing secondary occupations). This, however, happened only in the KHTM area.

\subsubsection{Climate change adaptation on livelihood activities}

In terms of livelihood activity adaptation, this study looked at three actions: (1) checking the weather before going to work, (2) making sure everything is ready before going to work, and

(3) checking flood-risk roads to avoid flooded routes and preparing a boat (as presented in Figure 5 that showed the boat's storage location in the house). As expected, the results revealed that the majority of households in all three areas of the U-Tapao River Sub-basin had implemented all three livelihood adaptation actions. This is understandable given that all three actions are simple and closely related to household activities. As a result, people find it relatively simple to adopt these adaptation options.

\subsection{Climate change adaptation challenges for households}

According to Table 3, the challenges that households in the U-Tapao River Sub-basin face when attempting to adapt appear to be similar. The most difficult factor that hampered people in the three areas was a lack of funds to take measures to reduce and/or adapt to the effects of climate change (PSAO $=82$ percent, $\mathrm{KHTM}=73$ percent, $\mathrm{PTSM}=67$ percent). The second most difficult factor impeding them from implementing adaptation strategies was a lack of knowledge about climate change adaptation practices, which was found in both PTSM and KHTM. The second most difficult factor for PSAO households was insufficient support from both local and provincial government agencies.

\section{CONCLUSIONS AND DISCUSSTION}

\subsection{Climate change impact}

Climate change has caused problems for people in the UTapao River Sub-basin in four major areas, according to our research: (1) health, (2) housing and property, (3) agriculture, and (4) general livelihood activities.

Extreme weather caused by climate change has had an impact on people's health, particularly their respiratory systems, as evidenced by the PSAO and KHTM cases. Climate change has an impact on both physical and biological systems, including the immune and respiratory systems, which are both critical to human health [30]. There is evidence that dengue outbreaks are linked to temperature, rainfall, and relative humidity [9]. Dengue fever was common in three locations, as it is in Nepal and many other parts of South Asia [31].

In terms of housing and property impacts, the flood caused by climate change destroyed people's homes, possessions, and property in these areas. Some people in the study areas (for example, in the case of PTSM) lived in one-story houses, making it impossible for them to protect their belongings from floods. As a result, whenever there was flooding, their homes and property were almost completely destroyed.

In terms of agricultural impact, para- rubber cannot be harvested during the dry season, resulting in a significant reduction in rubber latex yield. Previous research found that increasing rainfall and the number of rainy days resulted in 
fewer tapping days per year and lower para-rubber yields [17]. Fruit farmers in PSAO and KHTM were also impacted because their orchard fruit productivity was low due to changes in precipitation patterns caused by drought and flooding.

Finally, the floods had a significant impact on people's livelihoods in these three areas, both socially and economically. The rainy season made it difficult for shop owners in the study areas to run their businesses, and daily workers were unable to get to work. Economic activities were frequently severely disrupted, resulting in the loss of jobs, income, and people's overall well-being.

\subsection{Households' adoption of adaptation strategies}

The first category of household adaptation to climate change examined in this study is health adaptation. As expected, our research found that the majority of households in the U-Tapao River Sub-basin practiced both practices: (1) preparing prescription medications and having a first-aid kit on hand, and (2) preparing personal hygiene items and personal care. This finding is consistent with previous research, which found that preparing a first-aid kit, needed medications, and personal care and hygiene items are among general preparedness practices that most people can follow [32-36]. Furthermore, previous research has found that one of the most common disaster preparedness or climate change adaptation strategies is to save money for an emergency. However, our study found that households in the U-Tapao River Sub-basin were the least likely to save money for emergencies. Indeed, according to our findings, the majority of households cited a lack of funds as the most difficult impediment to adaptation.

Our findings show that the implementation of housing adaptation strategies such as elevating and reinforcing the house structure, building barricades to prevent flooding, and preparing sand bags to create a flood barrier was quite low among households in the U-Tapao River Sub-basin. According to the findings, when it comes to climate change adaptation, practices that necessitate structural changes, which are invariably associated with a significant financial outlay, may not be popular options for people with low to medium income. Based on our findings, this is not surprising, because the most difficult impediment for people in these areas is a lack of funds for adaptation. Previous research studies in other parts of the world have also mentioned this issue, namely that the most significant barrier to housing adaptation was a lack of funds [14, 16, 20, 37-39]. As a result, many households opt for less costly coping strategies such as raising beds, furniture, and assets. However, as Haque et al. [40] argue, these practices may not be able to help people adapt to the effects of climate change in a sustainable way because they are reactive rather than proactive. As a result, financial assistance from local, provincial, and national governments is required to encourage low- to middle-income households to pursue housing adaptation.

In terms of agricultural adaptation, our research found that the majority of households in the U-Tapao River Sub-basin did not implement all adaptation practices that were directly involved in adjusting or changing agricultural activities (or onfarm adaptation). Instead, as seen in KHTM, they chose secondary occupations as additional sources of income. One reason why households in our study areas did not implement on-farm adaptation measures was a lack of adequate knowledge, technical, and financial support. As a result, the simplest or least-expensive way for them to help themselves is to take any other jobs or temporary occupations to earn money. This finding is consistent with findings from previous studies conducted in other countries. In China, for example, Zhai et al. [23] discovered that some Chinese farmers chose to leave agriculture. Similarly, Aniah et al. [2] discovered that smallholder farmers preferred to use off-farm adaptation strategies, which included actions taken away from the farm. These off-farm adaptation strategies aid in mitigating the negative effects of climate change while requiring no financial investment.

Finally, our findings suggest that households in the UTapao River Sub-basin were capable of taking all three measures, namely, checking the weather before going to work, making sure everything is ready before going to work, and checking flood-risk roads to avoid flooded routes and preparing a boat. This is understandable, as previously stated, given that all three actions are simple and closely related to household activities. As a result, people find it relatively easy to adopt these adaptation options. Furthermore, and perhaps most intriguingly, people in our study areas understand how to use common farm or fishing equipment, such as boats, as climate change adaptation tools. Some households, as seen in PTSM and KHTM, keep their boats under their houses, ready to use when flooding occurs. In such cases, boats serve a purpose other than their usual one, they serve as a mode of transportation during extreme flooding.

\subsection{Major adaptation challenges for households}

The most difficult factor preventing people in the three areas of the U-Tapao River Sub-basin from taking measures to reduce and/or adapt to the effects of climate change was a lack of funds. This is critical because climate change adaptation requires money; therefore, a lack of financial resources severely limits households' ability to adapt and, eventually, exacerbates adaptation situations. Residents and community members, for example, can only use spontaneous and impactminimization measures for housing adaptation, rather than preventive actions, to effectively minimize flood impacts on their house and property. Lack of funds also limits households' ability to mitigate the effects of climate change on their farming activities [41]. Indeed, Zhai et al. [23] and Harvey et al. [19] discovered that farmers' ability to invest in their farms and adapt management practices to climate change is limited by limited financial resources. Furthermore, their research discovered a link between farm household income and farmers using a variety of adaptation measures (e.g., changing planting dates and using different crop varieties). More specifically, wealthier farmers are better able to manage the effects of climate change than those with limited financial resources.

\section{RECOMMENDATIONS}

This study looks at the impact of climate change on people in different parts of the river basin, specifically the upper, middle, and lower regions of the U-Tapao River Sub-basin. It addresses not only a wide range of contexts, but also a broad range of issues such as health, agriculture, and livelihood. Therefore, based on our research findings, we propose the following recommendations to help households in the UTapao River Sub-basin better adapt to the effects of climate 
change.

\subsection{Recommendations for adaptation funding}

Household adaptation can also be supported through the public budgets of international, national, and municipal governments because local people lack the financial resources to implement climate-change adaptation measures such as relocation and boat ownership. Local government budgets should be used as the primary source of funding for household adaptation activities. In the case of the private sector, it may be possible to establish a community fund in collaboration with local actors such as community-based organizations through corporate social responsibility (CSR) initiatives. Members of the community will have a channel to request financial support for their adaptation projects through this mechanism. National climate change and disaster risk reduction agencies should provide funding by allocating adaptation plan budgets to both provincial and local governments. Furthermore, funding may be provided by international organizations such as the Asian Cities Climate Change Resilience Network (ACCCRN), which can aid in the development of community capacity to adapt to the effects of climate change.

\subsection{Recommendations for adaptation in health and well- being}

Climate change may create conditions that exacerbate the Dengue fever situation. As a result, this threat to people's health in the U-Tapao River Sub-basin must be managed. Dengue fever can be eliminated by removing larval habitats and educating residents [42]. Other preventive measures, such as alerting people to changes in weather, temperature, and humidity, must also be implemented [31]. Residents should also participate by staying informed about important information $[18,43]$ and strictly adhering to medical doctors' or public health officers' orders.

\subsection{Recommendations for adaptation in housing}

To mitigate flooding's impact on the home and property, homeowners can use water-resistant materials, raise the floor level, and construct multistory homes [44]. However, these strategies require funding, and thus the support of related government agencies [45]. Along with these structural measures, local and provincial governments may also adopt non-structural measures. In terms of housing adaptation, some examples include relocating flood-prone development zones, creating or relocating flood-prone infrastructure, and updating building codes to require more flood-resistant structures in floodplains [21, 46].

\subsection{Recommendations for adaptation in agriculture}

Due to a lack of funds, knowledge, and technical assistance, on-farm adaptation was minimal in three study areas of the UTapao River Sub-basin. As a result, related agencies must provide assistance with plantation techniques, alternative farm management, and species selection. Aside from that, implementing adaptation strategies in agriculture necessitates the allocation of financial resources to farmers who are severely impacted by climate change [23, 47].
5.5 Recommendations for adaptation in general livelihood activities

Households in flood-prone areas should plan ahead of time to use alternate modes of transportation in the event that normal or main modes of transportation are rendered impractical due to massive flooding. Every household should prepare a boat, for example, that is ready to use in the event of flooding [22]. Local governments and related agencies should provide high trucks to assist people in commuting during times of flooding so that they can also go to work or get food. Furthermore, local governments should ensure that transportation systems and infrastructure are built or maintained in such a way that they can withstand extreme weather events such as heavy rain and flooding while also allowing for rapid emergency response [21, 31]. These measures can help to ensure the continuity of people's social and economic activities.

\section{ACKNOWLEDGEMENT}

This research project has been financially supported by National Research Council of Thailand. The authors greatly appreciated this support. The findings, conclusions and recommendations are those of the authors and do not necessarily reflect the views of the funding agency.

\section{REFERENCES}

[1] Tonmoy, F., Cooke, S., Armstrong, F., Rissik, D. (2020). From science to policy: Development of a climate change adaptation plan for the health and wellbeing sector in Queensland Australia. Environmental Science \& Policy, 108: 1-13. https://doi.org/10.1016/j.envsci.2020.03.005

[2] Aniah, P., Kaunza-Nu-Dem, M., Ayembilla, J. (2019). Smallholder farmers' livelihood adaptation to climate variability and ecological changes in the savanna agro ecological zone of Ghana. Heliyon, 5(4): e01492. https://doi.org/10.1016/j.heliyon.2019.e01492

[3] Intergovernmental Panel on Climate Change. (2014). Climate change 2014: impacts, adaptation, and vulnerability in Part A: Global and Sectoral Aspects. Contribution of Working Group II to the Fifth Assessment Report of the Intergovernmental Panel on Climate Change, In: Field, C.B., Barros, V.R., Dokken, D.J., Mach, K.J., Mastrandrea, M.D., Bilir, T.E., Chatterjee, M., Ebi, K.L., Estrada, Y.O., Genova, R.C., Girma, B., Kissel, E.S., Levy, A.N., MacCracken, S., Mastrandrea, P.R., White, L.L. (Cambridge; New York, NY: Cambridge University Press) https://www.ipcc.ch/report/ar5/wg2/./, accessed on Feb. 10, 2021.

[4] Bennett, N.J., Dearden, P., Murray, G., Kadfak, A. (2014). The capacity to adapt?: communities in a changing climate, environment, and economy on the northern Andaman coast of Thailand. Ecology and Society, 19(2): 5. http://dx.doi.org/10.5751/ES-06315190205

[5] Whitney, C.K., Bennett, N.J., Ban, N.C., Allison, E.H., Armitage, D., Blythe, J.L., Burt, J.M., Cheung, W., Finkbeiner, E.M., Kaplan-Hallam, M.K., Perry, R.I., Turner, N.J., Yumagulova, L. (2017). Adaptive capacity: 
from assessment to action in coastal social-ecological systems. Ecology and Society, 22(2): 22. https://doi.org/10.5751/ES-09325-220222

[6] Tahiru, A., Sackey, B., Owusu, G., Bawakyillenuo, S. (2019). Building the adaptive capacity for livelihood improvements of Sahel Savannah farmers through NGOled adaptation interventions. Climate Risk Management, 26: 100197. https://doi.org/10.1016/j.crm.2019.100197

[7] Füssel, H. (2007). Adaptation planning for climate change: Concepts, assessment approaches, and key lessons. Sustainability Science, 2(2): 265-275. https://doi.org/10.1007/s11625-007-0032-y

[8] Vescovi, L., Rebetez, M., Rong, F. (2005). Assessing public health risk due to extremely high temperature events: climate and social parameters. Climate Research, 30(1): 71-78. https://doi.org/10.3354/cr030071

[9] Naish, S., Dale, P., Mackenzie, J.S., McBride, J., Mengersen, K., Tong, S. (2014). Climate change and dengue: A critical and systematic review of quantitative modelling approaches. BMC Infectious Disease, 14: 167. https://doi.org/10.1186/1471-2334-14-167

[10] Mohd, T., Mohamed Saraf, M.H., Che Pin, S.F., Hasbullah, M.N., Nordin, T.E., Ismail, D. (2016). The degree of housing damage model for a flood affected area. MATEC Web of Conferences, 66(4): 00074. https://doi.org/10.1051/matecconf/20166600074

[11] Selm, K., Hess, G., Peterson, M., Beck, S., McHale, M. (2018). Developing an instrument to measure autonomous adaptive capacity to climate change among urban households. Frontiers in Ecology and Evolution, 6: 1-9. https://doi.org/10.3389/fevo.2018.00013

[12] Svetlana, D., Radovan, D., Ján, D. (2015). The economic impact of floods and their importance in different regions of the world with emphasis on Europe. Business Economics and Management 2015 Conference, BEM2015, Procedia Economics and Finance, 34: 649655.

[13] Limsakul, A., Kachenchart, B., Singhruck, P., Saramul, S., Santisirisomboon, J., Apipattanavis, S. (2019). Updated basis knowledge of climate change summarized from the first part of Thailand's second assessment report on climate change. Applied Environmental Research, 41(2): 1-12. https://doi.org/10.35762/AER.2019.41.2.1

[14] Assan, E., Suvedi, M., Schmitt Olabisi, L., Bansah, K.J. (2020). Climate change perceptions and challenges to adaptation among smallholder farmers in semi-arid Ghana: A gender analysis. Journal of Arid Environments, 182: http://dx.doi.org/10.1016/j.jaridenv.2020.104247

[15] Mu, L., Fang, L., Liu, Y., Wang, C. (2020). Identifying barriers and enablers for climate change adaptation of farmers in semi-arid north-western China. Sustainability, 12(18): http://dx.doi.org/10.1016/j.jaridenv.2020.104247

[16] Forino, G., von Meding, J., Brewer, G., van Niekerk, D. (2017). Climate change adaptation and disaster risk reduction integration: strategies, policies, and plans in three Australian local governments. International Journal of Disaster Risk Reduction, 24: 100-108. https://doi.org/10.1016/j.ijdrr.2017.05.021

[17] Somboonsuke, B., Phitthayaphinant, P., Sdoodee, S., Kongmanee, C. (2018). Farmers' perceptions of impacts of climate variability on agriculture and adaptation strategies in Songkhla Lake basin. Kasetsart Journal of
Social Sciences, 39(2):

https://doi.org/10.1016/j.kjss.2018.05.006

277-283.

[18] Lin, A.S., Chompikul, J., Mongkolchati, A. (2017). Determinants of preventive behaviour against dengue haemorrhagic fever among caregivers of children in Magway Township, Myanmar. Journal of Public Health and Development, 15(3): 65-78.

[19] Harvey, C.A., Saborio-Rodríguez, M., MartinezRodríguez, M.R., Viguera, B., Chain-Guadarrama, A., Vignola, R., Alpizar, F. (2018). Climate change impacts and adaptation among smallholder farmers in Central America. Agriculture \& Food Security, 7(1): 1-20. https://doi.org/10.1186/s40066-018-0209-X

[20] Lehmann, P., Brenck, M., Gebhardt, O., Schaller, S., Süßbauer, E. (2015). Barriers and opportunities for urban adaptation planning: analytical framework and evidence from cities in Latin America and Germany. Mitigation and Adaptation Strategies for Global Change, 20(1): 7597. https://doi.org/10.1007/s11027-013-9480-0

[21] Birchall, S.J., Bonnett, N. (2021). Climate change adaptation policy and practice: The role of agents, institutions and systems. Cities, 108: 103001. https://doi.org/10.1016/j.cities.2020.103001

[22] Artur, L., Hilhorst, D. (2012). Everyday realities of climate change adaptation in Mozambique. Global Environmental Change, 22(2): 529-36. http://dx.doi.org/10.1016/j.gloenvcha.2011.11.013

[23] Zhai, S., Song, G., Qin, Y., Ye, X., Leipnik, M. (2018). Climate change and Chinese farmers: Perceptions and determinants of adaptive strategies. Journal of Integrative Agriculture, 17(4): 949-963. http://doi.org/10.1016/S2095-3119(17)61753-2

[24] Molina-Azorin, J.F. (2016). Mixed methods research: An opportunity to improve our studies and our research skills. European Journal of Management and Business Economics, 25(2): 37-38. https://doi.org/10.1016/j.redeen.2016.05.001

[25] Dawadi, S., Shrestha, S., Giri, R. A. (2021). Mixedmethods research: A discussion on its types, challenges, and criticisms. Journal of Practical Studies in Education, 2(2): 25-36. https://doi.org/10.46809/jpse.v2i2.20

[26] Ober, K., Sakdapolrak, P. (2020). Whose climate change adaptation 'barriers'? Exploring the coloniality of climate change adaptation policy assemblages in Thailand and beyond. Singapore Journal of Tropical Geography, 41(1): 86-104. https://doi.org/10.1111/sjtg.12309

[27] Gyawali, S., Techato, K., Yuangyai, C., Musikavong, C. (2013). Assessment of relationship between land uses of riparian zone and water quality of river for sustainable development of River Basin, a case study of U-Tapao River Basin, Thailand. Procedia Environmental Sciences, 17: https://doi.org/10.1016/j.proenv.2013.02.041

[28] Chuvanich, S., Chevakidagarn, P., Heb, B., Phongdara, A., Thongnoo, K. (2017). Water quality index assessment for the trend of water quality in U-tapao canal sub-basin, southern part of Thailand. In proceeding of the ACENS- 2017 (Asian Conference on Engineering and Natural Sciences), Japan. https://doi.org/10.1515/jwld2017-0087

[29] Southern Regional Center of Geo-Informatics and Space Technology, Prince of Songkla University. (2021). Studied areas in Songkhla Lake Basin Map. 
https://www.gispsu.net/files/com_public_download/202 1 -

11_36c0525d78bb25e.jpg?fbclid=IwAR2kZsDAQiMq EQUd5JN0M0hS42XIHcWBGv_RFRM68fuf8XLPZ9 RbnKEHiWk, accessed on Nov. 10, 2021.

[30] D'Amato, G., Cecchi, L., D'Amato, M., AnnesiMaesano, I. (2014). Climate change and respiratory diseases. European Respiratory Review, 23(132): 161169. https://doi.org/10.1183/09059180.00001714

[31] Pandey, B.D., Costello, A. (2019). The dengue epidemic and climate change in Nepal. The Lancet, 394(10215): 2150-2151. 6736(19)32689-3

[32] Baker, E. J. (2011). Household preparedness for the aftermath of hurricanes in Florida. Applied Geography, 31(1):

46-52. https://doi.org/10.1016/j.apgeog.2010.05.002

[33] Cretikos, M., Eastwood, K., Dalton, C., Merritt, T., Tuyl, F., Winn, L., Durrheim, D. (2008). Household disaster preparedness and information sources: Rapid cluster survey after a storm in New South Wales, Australia. BMC Public Health, 8(1): 195. https://doi.org/10.1186/1471-2458-8-195

[34] DeBastiani, S.D., Strine, T.W., Vagi, S.J., Barnett, D.J., Kahn, E.B. (2015). Preparedness perceptions, sociodemographic characteristics, and level of household preparedness for public health emergencies: Behavioral risk factor surveillance system, 2006-2010. Health Security, $\quad$ 13(5): 317-326. https://doi.org/10.1089/hs.2014.0093

[35] Eisenman, D.P., Cordasco, K.M., Asch, S., Golden, J.F., Glik, D. (2007). Disaster planning and risk communication with vulnerable communities: Lessons from Hurricane Katrina. American Journal of Public Health, $\quad$ 97(Supplement_1): S109-S115. https://doi.org/10.2105/AJPH.2005.084335

[36] Gargano, L.M., Caramanica, K., Sisco, S., Brackbill, R. M., Stellman, S. D. (2015). Exposure to the World Trade Center disaster and 9/11-related post- traumatic stress disorder and household disaster preparedness. Disaster Medicine and Public Health Preparedness, 9(6): 625-633. https://doi.org/10.1017/dmp.2015.71

[37] Di Giulio, G.M., Bedran-Martins, A.M.B., Vasconcellos, Md.P., Ribeiro, W.C., Lemos, M.C. (2018). Mainstreaming climate adaptation in the megacity of São Paulo, Brazil. Cities, 72: 237-244. https://doi.org/10.1016/j.cities.2017.09.001

[38] Whitney, C.K., Ban, N.C. (2019). Barriers and opportunities for social-ecological adaptation to climate change in coastal British Columbia. Ocean \& Coastal
Management, 179: 104808. https://doi.org/10.1016/j.ocecoaman.2019.05.010

[39] Robledo-Buitrago, D.A., Polanco-Puerta, M.F., De Luque-Villa, M., Mesa-Caro, M., Calderón-Ricardo, C.A. (2021). Climate change trends in Colombia: A case study in Facatativá, Cundinamarca. International Journal of Sustainable Development and Planning, 16(3): 535542. https://doi.org/10.18280/ijsdp.160314

[40] Haque, A.N., Dodman, D., Hossain, M.M. (2014). Individual, communal and institutional responses to climate change by low-income households in Khulna, Bangladesh. Environment and Urbanization, 26(1): 11229. https://doi.org/10.1177/0956247813518681

[41] González-Hernández, D.L., Meijles, E.W., Vanclay, F. (2019). Household barriers to climate change action: Perspectives from Nuevo Leon, Mexico. Sustainability, 11(15): 4178. https://doi.org/10.3390/su11154178

[42] Satterthwaite, D., Huq, S., Pelling, M., Reid, H., Lankao, P.R. (2007). Adapting to climate change in urban areas the possibilities and constraints in low- and middleincome nations: human settlements discussion paper series theme: Climate change and cities. In the Human Settlements Group and the Climate Change Group. International Institute for Environment and Development (IIED).

[43] Rasheed, H., Keikarnka, B., Chompikul, J. (2010). Disaster preparedness behaviour among rural people in Gaafu Dhaalu Atoll, Maldives. Journal of Public Health and Development, 8(1): 9-20.

[44] Tikul, N. (2015). Suitable low income flood resilient housing. Applied Environmental Research, 37(3): 1-11.

[45] Porter, J.J., Dessai, S., Tompkins, E.L. (2014). What do we know about UK household adaptation to climate change? A systematic review. Climatic Change, 127(2): 371-379. https://doi.org/10.1007/s10584-014-1252-7

[46] United Nations-Habitat (UN-Habitat). (2012). Developing Local Climate Change Plans: A Guide for Cities in Developing Countries. Nairobi, Kenya, 2012. https://unhabitat.org/sites/default/files/downloadmanager-

files/Developing\%20Local\%20Climate\%20Change\%20 Plans.pdf /, accessed on Feb. 10, 2021.

[47] Mabon, L., Nguyen, S.T., Pham, T.T., Tran, T.T., Le, H.N., Doan, T.T.H., Hoang, T.N.H., Natascha, M.H., Stephens, V. (2021). Elaborating a people-centered approach to understanding sustainable livelihoods under climate and environmental change: Thang Binh District, Quang Nam Province, Vietnam. Sustainability Science, 16(1): 221-238. https://doi.org/10.1007/s11625-02000861-3 